\title{
STUDY ON SOME FACTORS AFFECTING THE MANUFACTURING OF CATTLE FEED PELLETS
}

\author{
Mahmoud M.A. Bakr ${ }^{1 *}$, M.A.El-Shazly ${ }^{2}$, M.A. Tawfik ${ }^{2}$ and Y.S. Abdallah ${ }^{2}$ \\ 1. Agric. Eng. Dept., Fac. Agric., Damietta Univ., Egypt \\ 2. Agric. Eng. Dept., Fac. Agric., Zagazig Univ., Egypt
}

\begin{abstract}
The overall goal of the present study is evaluating the performance of extrusion machine to produce a strong and durable cattle feed pellets with minimum cost using a partial replacement of rice straw in the standard cattle ration (control). Some operating parameters affecting the performance of machine were evaluated under different feeding rates of 100, 200, 300 and $400 \mathrm{~kg} / \mathrm{hr}$., two percentages of rice straw residue $12.5,25 \%$ and control, three distances between die and screw (compression room) $1,1.5$ and $2 \mathrm{~cm}$, three holes diameters 8,11 and $14 \mathrm{~mm}$ using constant ration moisture content of $30 \%(\mathrm{wb})$ taking into consideration machine productivity, pellets quality, pelleting efficiency, energy requirements and total costs. From the obtained results, the extrusion machine could be operated with rice straw percentage of $12.5 \%$, die hole diameter of $8 \mathrm{~mm}$, screw-die distance of $2 \mathrm{~cm}$ and feeding rate of $400 \mathrm{~kg} / \mathrm{hr}$., to achieve the highest values of bulk density of $1.121 \mathrm{~g} / \mathrm{cm}^{3}$, pellet durability of $90.70 \%$ and pelleting efficiency of $82.52 \%$ with machine productivity of $92.34 \mathrm{~kg} / \mathrm{hr}$., energy requirements of $269 \mathrm{~kW} . \mathrm{hr} . / \mathrm{Mg}$ and pelleting total cost of $2394.90 \mathrm{LE} / \mathrm{Mg}$. The results revealed that $12.5 \%$ replacement of rice straw in the standard ration with the previous parameters saved about 236.91 LE/Mg.
\end{abstract}

Key words: Extruder, cattle pellets, rice straw, partial replacement, pellet quality, total cost.

\section{INTRODUCTION}

Agricultural residues represent an extreme problem in Egypt facing the people and government from economic, environmental and healthy aspects. However, it is possible to get benefits from these agricultural wastes through some application utilization such as animal feed, organic fertilization, and small industries like wood, paper and etc.

In Egypt, the agricultural residues are about 30 million tons only about $38 \%$ was recycled in 2014. So we need an economical process to improve and increase the utility of the agricultural residues especially as a cattle feed pellets (Environmental Statistics, 2014).

Dobermann and Fairhust (2000) mentioned that, in many farms massive amounts of post- harvest rice residues are eliminated through open air field burning, to save time to prepare the land for the next crops. Burning of rice straw is environmentally unacceptable as it leads to (1) release of soot particles and smoke causing human health problems such as asthma or other respiratory problems, (2) emission of greenhouse gases such as carbon dioxide, methane and nitrous oxide $\left(\mathrm{N}_{2} \mathrm{O}\right)$ causing global warming and (3) loss of plant nutrients. Moreover, the traditional way of storing the crop residues in the farms and houses roofs gives unlimited chance for the possibility to fire these residues.

Abdel-Motteleb (1993) stated that the field crop residues can be reutilized instead of getting rid of it by burning which causes air pollution.

\footnotetext{
*orresponding author: Tel. : +201002233705

E-mail address: m20503@yahoo.com
} 
El-Zahaby (1996) mentioned that there is a large amount of residues all over the Egyptian farms. He also made a complete survey of field crop residues in Egypt and suggested to use these residues as follow:

1. Utilization of some field crop residues in production of thermal energy.

2. Using of some field crop residues for producing of unconventional bricks which can be used for building farmer houses.

3. Utilization of some field crop residues for production of unconventional cattle feeding.

Gaur and Sadasivam (1993) stated that rice straw is the most important crop- residue in world and it has a various uses such as; cattle feed, thatch mulch and spent mushroom compost and etc.

On the other hand, there is a great shortage in animal feed stuff, which is one of the most serious problems facing breeders. The rate of increase in the production of animal feed in Egypt is not parallel with the increase of the number of livestock. Therefore, the gap of forage and cattle feed is very large in Egypt and there is an urgent need to produce very large amounts of feed in various forms such as; feed pellets, especially. The animal feed accounts for about $70 \%$ over the total costs of the production process for various kinds of livestock.

Devendra and Sevilla (2002) showed that ruminant livestock plays a very important role as an integral part of farming and the rural life countries; providing food, family income and employment. Wanapat et al. (2012) stated that these ruminants mainly depend on crop residue such as; rice straw and native pastures which are low in nutritive value in terms of low crude protein (CP) and high in structural carbohydrate. Rice straw is the main crop residue which is stored by farmers for use as a ruminant feed throughout the year especially in the dry season. Generaly, the ability of microorganisms in cattle rumen to degrade and digeste fibrous materials such as; rice straw encouraged the breeders to make a partial replacement of rice straw in the standard cattle ration to reduce the production cost.
NRC (2001) reported that adequate dietary fiber is very important for dairy cattle to maintain rumen health and optimize ruminal microbial efficiency.

Behnke (1994) mentioned that pelleting process provides the possibility of using increased proportions of crop residues and byproducts in order to substitute for cereal grains. pelleting can decrease feed wastage, reduce selective feeding, decrease ingredient segregation, less time and energy expended for prehension destruction of pathogenic organisms, thermal modification of starch and protein and improved palatability, create a homogeneous mixture preventing the avoidance of some ingredients by the cattle, reduce feed waste, improve the efficiency of feed intake, eliminate harmful bacteria and, by means of a suitable diet preparation and improve its digestibility.

So, it's possible to introduce the cattle feed in pellets form having the all nutrients using extrusion method.

Nehru et al. (2005) stated that Extrusion processing is considered one of the new processing of high technology in food and feed industry. Both the geometrical dimension of die and ration components are the most important parameters influencing the efficiency of extrusion machine and pellets quality. Extrusion processing allows greater formulation flexibility, versatility in size and shape, increased shelf life and has higher feed efficiency due to proper heat treatment.

Harper and Jansen (1981) indicated that there are two types of extruders: single screw and twin-screw extruders and each type have a specific range of application.

Hauck (1993) mentioned that the screw speed is one of the main factors that influence the performance of the extruder: it affects the residence time of the product, the amount of frictional heat generated, heat transfer rates and the shearing forces on the product.

Blass and Wiseman (1998) explained that overall die diameter and length are the most important factors associated with pelleting in the die because of the large number of variables associated with the number and position of the holes. 
Gupta and Goyal (1999) mentioned that the size of the pellets varies from $8 \mathrm{~mm}$ to $38 \mathrm{~mm}$ in diameter and 20-60 $\mathrm{mm}$ in length depending upon the need of different animals.

Kaddour (2003) stated that when screw speed increased from 1.01 to 1.4 and up to $1.81 \mathrm{~m} / \mathrm{sec}$. the energy requirements decreased by 12.72 and $16.20 \%$ under fineness degree of $2 \mathrm{~mm}$, also energy requirements increased by increasing the effective hole from 19.5 to $25.5 \mathrm{~mm}$. by 8.89 , 11.72 and $17.80 \%$ at screw speed of $1.81 \mathrm{~m} / \mathrm{sec}$.

Kaddour et al. (2006) decided that both the geometrical dimensions of die and rations components are the most important parameters influencing the efficiency of extrusion machine and the quality of pellets.

Blass and Wiseman (1998) explained that the energy consumed by the pellet mill is directly related to compaction capacity and therefore it in is related to die length and hole diameter.

Watfa (1999) stated that increasing die hole diameter from 4 to $8 \mathrm{~mm}$. reduced specific energy by $42 \%$, pelleting pressure by $35 \%$ and bulk density by $15 \%$.

Kaddour (2003) found that increase of screw speed from 1.01 to $1.41,1.81$ and $2.2 \mathrm{~m} / \mathrm{sec}$., increased pellets durability by $0.56,4.28,4.29$ and $16.2 \%$ under milling fineness degree of $2 \mathrm{~mm}$, and number of holes of 22 using effective hole diameter of $25.5 \mathrm{~mm}$.

Gupta and Goyal (1999) mentioned that at developed an animal feed pelleting machine for producing poultry feed pellets, the machine was operated with $7.5 \mathrm{hp}$ electric motor. The capacity of the machine ranged between 60 to $85 \mathrm{~kg} / \mathrm{hr}$., depending upon diameter of dies.

Kaddour (1999) found that the cost LE per ton decreased sharply by using the residues diet by $24.12 \%, 24.43 \%, 24.75 \%$ and $24.95 \%$ at concave using mixing speed of $70 \mathrm{rpm}$ and die hole shape without relief hole diameter of 1.2.3 and $4 \mathrm{~mm}$ respectively.

So, the objectives of this study are:

1. Producing pellets for feeding cattle using extrusion machine with partial replacement of rice straw as an agricultural residue in the standard ration for reducing the production cost.
2. Determining some operating parameters affecting the performance of cattle pelleting machine and pellet quality.

3. Estimating the operational cost of cattle feed pelleting.

\section{MATERIALS AND METHODS}

The practical experiments were carried out in the fodder manufacturing unit at Central Laboratory for Aquaculture Research in Abbassa, Abou Hammad district, Sharkia Governorate through 2015. The extrusion machine was used for research and feed production purposes.

\section{Materials}

\section{Cattle ration}

The experimental ration is prepared by a hammer mill and mixed in forage mixer with $30 \%$ moisture content of total mass. Moisture content was determined by using the standard methods. The composition of the standard experimental ration and after rice straw replacement is shown in Table 1.

\section{Rice straw}

The moisture content of used rice straw was $7 \%$. The percentage of rice straw was prepared by using hammer mill (Entag hammer mill, local made model, overall length $1.70 \mathrm{~cm}$, over all width $60 \mathrm{~cm}$, overall high $270 \mathrm{~cm}, 16$ rectangular knives shape, $1 \mathrm{~mm}$ concave clearance) in ECARU company with $0.8 \mathrm{~mm}$ diameter of screen holes according to (Turner, 1995).

\section{The specifications of extrusion pelleting machine}

Figs. 1 and 2 show the extrusion pelleting machine that mainly consists of the following parts:

\section{Main frame}

The main frame is made from iron steel Lsection with $2000 \mathrm{~mm}$ in length, $1875 \mathrm{~mm}$ in width and $980 \mathrm{~mm}$ in height .Main frame is a base which carrying feeding unit, pressing unit and main electric power motor. 
Table 1. Composition of standard cattle ration and after rice straw replacement*

\begin{tabular}{lccc}
\hline Composition (standard) & Percentage (\%) & \multicolumn{2}{c}{ Rice straw replacement (\%) } \\
\cline { 2 - 4 } & & $\mathbf{1 2 . 5}$ & $\mathbf{2 5}$ \\
\hline Corn (yellow grain) & 65 & 56.875 & 48.75 \\
Soy-bean meal & 10 & 8.75 & 7.5 \\
Cotton seed meal & 10 & 8.75 & 7.5 \\
Wheat bran & 6 & 5.25 & 4.5 \\
Soybean oil & 1.5 & 1.3125 & 1.125 \\
Carbonate sodium & 0.7 & 0.6125 & 0.525 \\
Sodium chloride & 0.3 & 0.2625 & 0.225 \\
Magnesium sulfate( Epsom salt ) & 0.1 & 0.0875 & 0.075 \\
Saccharomyces cervicease yeast & 0.5 & 0.4375 & 0.375 \\
Rice bran & 5.5 & 4.8125 & 4.125 \\
Anti-toxin & 0.1 & 0.0785 & 0.075 \\
Premix & 0.3 & 0.2625 & 0.225 \\
Total & $\mathbf{1 0 0 \%}$ & $\mathbf{1 0 0 \%}$ & $\mathbf{1 0 0 \%}$ \\
\hline
\end{tabular}

* According to the obtained knowledge from animal feeding research section, agriculture research center.

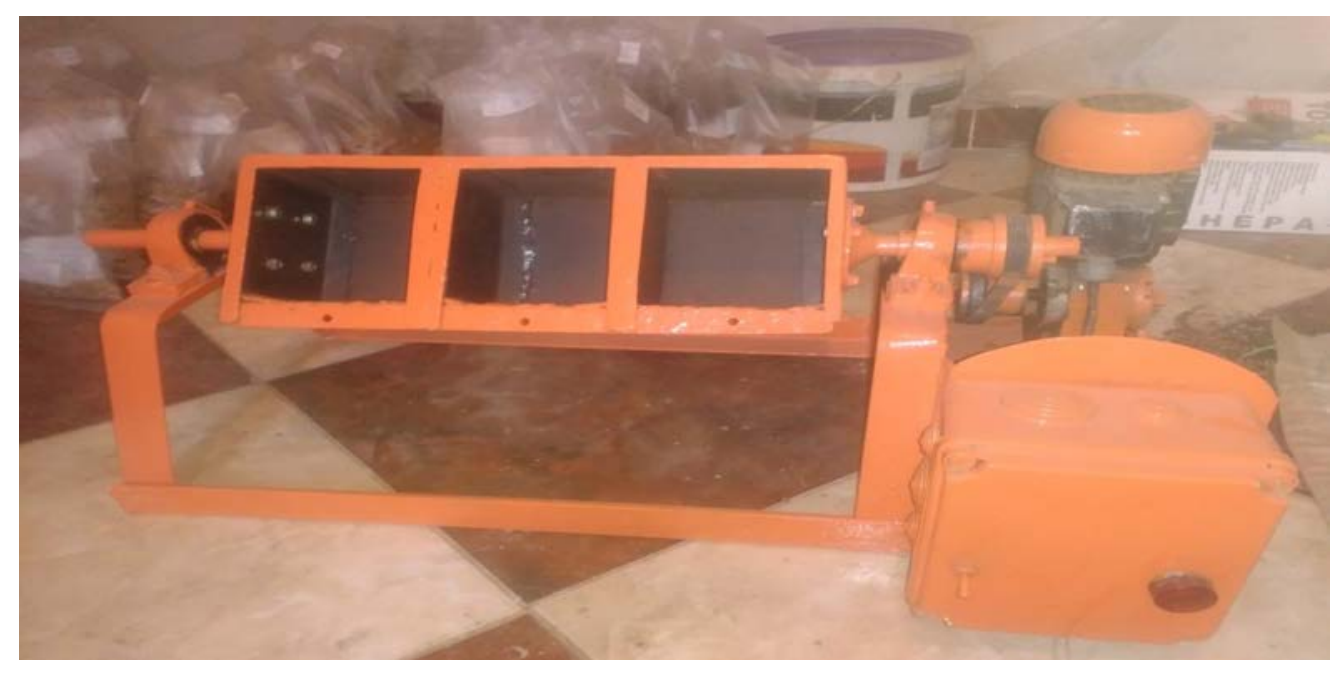

Fig. 1. Photo of durability turning box 


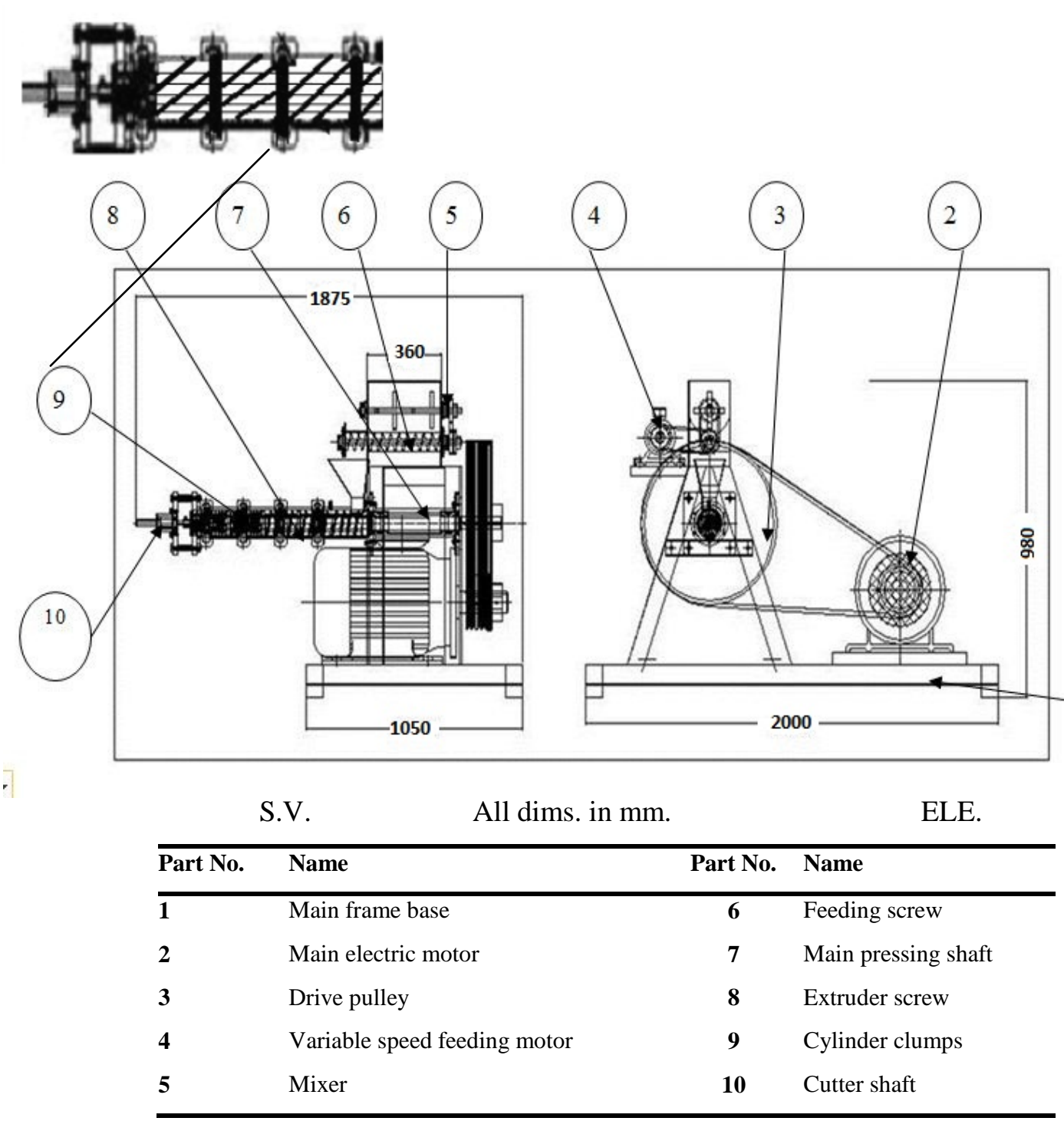

Fig. 2. Schematic draw of the extrusion machine, Zaki et al. (2014)

\section{Feeding hopper}

Feeding hopper was made of steel sheet with $2 \mathrm{~mm}$ thickness with $360 \mathrm{~mm}$ in length, $280 \mathrm{~mm}$ in width and $620 \mathrm{~mm}$ in height with maximum capacity of about $30 \mathrm{~kg}$ provided with sliding gate at the bottom to control the ration flow from the hopper to the forming unit.

\section{Feeding screw}

Feeding screw has dimensions of $550 \mathrm{~mm}$ in length, $49 \mathrm{~mm}$ diameter and pitch of $35 \mathrm{~mm}$; it is located in the bottom of feeding hopper to transmit the ration from feeding unit to extrusion unit. It takes the power from an electrical variable speed motor.

\section{Extruder cylinder}

The dimensions of extrusion machine cylinder were $300 \mathrm{~mm}$ in length, $190 \mathrm{~mm}$ internal diameter and $10 \mathrm{~mm}$ in thickness. The extruder cylinder is made of cast iron with incisions in the internal surface to impress the ration pass forward with screw direction.

\section{Compressing screw}

The compressing screw has dimensions of $300 \mathrm{~mm}$ in length, $185 \mathrm{~mm}$ in diameter and 
pitch of $70 \mathrm{~mm}$. There is bolt assembled in the last screw to hold all screw parts with the main shaft which has $10.4 \mathrm{~mm}$ diameter, the internal surface has incisions to let the ration through it, the extrusion machine screw is made of iron metal.

\section{Forming die}

The forming die was assembled in die house by bolts $14 \mathrm{~mm}$ diameter and this part blocked the last cylinder from the end of extrusion machine, clearance between the die and extrusion machine screw around $3 \mathrm{~cm}$. The die dimensions are $108 \mathrm{~mm}$ diameter exterior,73 $\mathrm{mm}$ diameter interior and $23 \mathrm{~mm}$ total thicknesses, there are three types of die, die 8 $\mathrm{mm}$ hole diameter which has 25 holes in its surface, die $11 \mathrm{~mm}$ hole diameter with 13 holes in its surface and die $14 \mathrm{~mm}$ hole diameter with 8 holes in its surface. The total open area in each die was $153.86 \mathrm{~mm}^{2}$.

\section{Main motor}

Main electric motor with output power of $37.3 \mathrm{k} . \mathrm{W} ., 43 \mathrm{~A}$., is used for operating the machine, the motor assembled on the base by four bolts. Power is transmitted from main motor to the extruder shaft by a pulley (diameter of $224 \mathrm{~mm}$.) and five (V) belts.

\section{Feeder motor}

Variable mechanical gearbox motor is used to control motor shaft speed ,it has output power of $1.5 \mathrm{K.W}$. and $18 \mathrm{~A}$., it has a manual key to increase and decrease feeding rate. Motor shaft speed ranged from $28 \mathrm{rpm}$ to $160 \mathrm{rpm}$. Power transmited to feeder screw shaft and feeder mixer shaft by gears and sprockets.

\section{Cutter motor}

Cutter motor connected with cutter knife by a shaft which has dimensions of $180 \mathrm{~mm}$. length and $15 \mathrm{~mm}$ diameter. Motor has an output power of 0.746 k.W., 12 A. Cutting speed can be controlled by inverter which increase and decrease motor shaft speed from zero to maximum motor shaft speed.

\section{Durability turning box}

A durability turning box consists of three cells $(14 \times 12 \times 13 \mathrm{~mm})$ rotated at constant speed of $60 \mathrm{rpm}$ and has $0.5 \mathrm{hp}$ motor power. It was used for measuring pellets durability.

\section{Methods}

Experiments were conducted to optimize some operating parameters affecting the performance of extrusion machine and the effect of the partial replacement of rice straw in the cattle ration on the pellet quality with a constant opening area of $153.86 \mathrm{~mm}^{2}$ for each die, die 8 $\mathrm{mm}$ hole diameter has 25 holes, die $11 \mathrm{~mm}$ hole diameter has 13 holes and die $14 \mathrm{~mm}$ hole diameter has 8 holes, using the following variables:

1.Four different feeding rates of $100,200,300$ and $400 \mathrm{~kg} / \mathrm{hr}$.

2.Two partial replacement of rice straw which were 12.5 and $25 \%$ in addition to the control treatment (standard ration).

3.Three screw-die distances of $1,1.5$ and $2 \mathrm{~cm}$.

4.Three hole diameters of 8,11 and $14 \mathrm{~mm}$.

The evaluation of the above mentioned parameters was taken into consideration in the following indicators:

\section{Extruder productivity}

The extruder productivity was measured by collecting the pellet samples for a known time. During the experiments the pellets were collected for every 20 seconds and the productivity was calculated in $\mathrm{kg} / \mathrm{hr}$. Three measurements were made for each experimental run and then averaged.

Productivity $(\mathrm{kg} / \mathrm{hr})=.\frac{\mathrm{Wp}}{\mathrm{T}} \times 3.6$ (Kaddour, 2003) Where:

Wp: pellets mass (g)

$\mathrm{T}$ : consumed time (sec.)

\section{Pellets bulk density}

The bulk density of the pellets decides the storage space required at the feed production units, cattle farms and also during transportation. The size, shape and method of filling affect the bulk density of the pellets. 

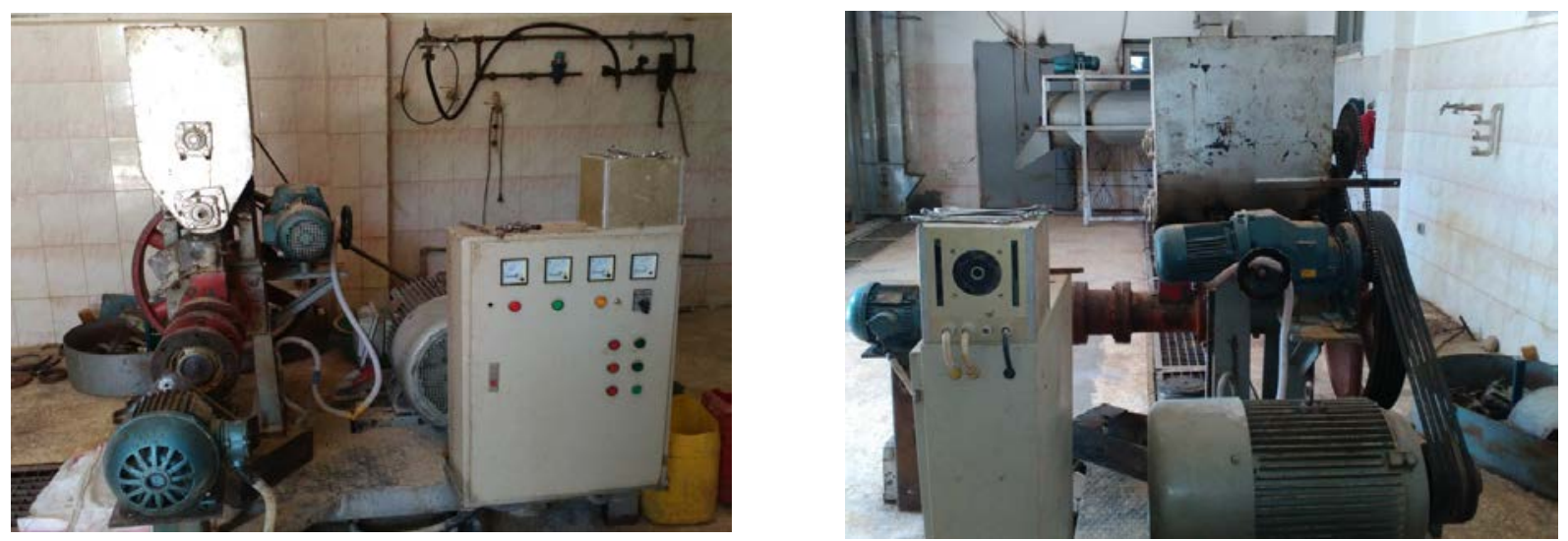

Figs. 2 and 3. Two photos of the extrusion machine

It was calculated using the following equation:

Pellets bulk density $=\mathrm{W}_{\mathrm{d}} / \mathrm{V}_{\mathrm{d}}, \mathrm{g} / \mathrm{cm}^{3}$

Where:

$\mathrm{W}_{\mathrm{d}}$ : pellets sample mass, $\mathrm{g}$.

$\mathrm{V}_{\mathrm{d}}$ : pellets sample volume, $\mathrm{cm}^{3}$ (Kaddour, 2006)

\section{Pellet durability}

Pellet durability was determined according to ASAE standards method S269.4 DEC01 (ASAE, 1996). Five hundred grams of the pellets were tumbled inside a pellet durability tester for 10 minutes and sieved. The pellet durability was calculated as

Pellet durability $=\left(\frac{M_{a t}}{M_{b t}}\right) \times 100$

Where:

$\mathrm{M}_{\mathrm{at}}$ : Pellets mass after tumbling, g.

$\mathrm{M}_{\mathrm{bt}}$ : Pellets mass before tumbling, $\mathrm{g}$.

\section{Pelleting efficiency}

It was calculated from the following formula:

Pelleting efficiency $=\frac{\mathrm{Wp}}{\mathrm{Wm}} \times 100 \% \quad($ Zaki, 2014)

Where:

Wp: pellets mass, g.

Wm: total mass of sample, g.

\section{The total consumed power}

It was calculated according to the following equation:
Consumed power $=\frac{\sqrt{3} \mathrm{IV} \eta \cos \theta}{1000}, \mathrm{~kW}($ Kurt, 1979).

Where:

I = Line current strength in amperes.

$\mathrm{V}=$ Potential difference (Voltage) being equal to $380 \mathrm{~V}$.

$\operatorname{Cos} \theta=$ Power factor (being equal to 0.84 ).

$\sqrt{3}=$ Coefficient current three phase (being equal 1.73).

$\eta=$ Mechanical efficiency assumed (90\%).

\section{Energy requirement}

Energy requirement were obtained using the following formula:

Energy requirement $=$

$\frac{\text { Consumed power (k.W) }}{\text { Extruder productivity (Mg/hr.) }}$, kW.hr./Mg

\section{Operation Cost}

The cost analysis was performed considering the conventional method of estimating both fixed and variable cost, The total cost included the cost of standard ration components, rice straw, machine depreciation, interest and miscellaneous cost, labor, electricity and repair and maintenance costs.

\section{Calculation of fixed costs}

Depreciation costs

Deprecation $=\frac{\text { Initial price }- \text { Salvage value }}{\text { Useful life in hours }}($ Zaki, 2014) 
Salvage value has been assumed as 0.1 of the initial price.

\section{Interest cost}

Interest $=\frac{(\text { Unit price }+ \text { Salvage value }) \times 0.18}{2 \times \text { yearly operation hours }}($ Zaki, 2014 $)$

\section{Miscellaneous costs}

Miscellaneous costs $=(\mathrm{V}+\mathrm{F}) \times 0.05(\mathrm{Zaki}, 2014)$

Where:

$\mathrm{V}=$ Variable costs.

$\mathrm{F}=$ Fixed costs.

$0.05=$ Coefficient of miscellaneous costs as a percentage of variable and fixed costs.

\section{Calculation of variable costs}

\section{Labor cost}

The cost of labor varies with location, hence the prevailing wage rate for labor was found to be $5 \mathrm{LE} \cdot \mathrm{Mg}^{-1}$. The number of labor was one.

\section{Electricity costs}

The cost of electricity was determined according to the following equation:

Electricity consumption $=0.86 \mathrm{LE} \cdot \mathrm{kW}^{-1}$.

\section{Repair and maintenance costs}

The repair and maintenance costs were determined according to the following:

Repair and maintenance costs $=90 \%$ deprecation (Zaki, 2014)

\section{RESULTS AND DISCUSSION}

Obtained results will be discussed under the following heads.

\section{Effect of Some Operating Parameters on Extruder Productivity}

Fig. 4 show that, as the feed rate increased from 100 to $300 \mathrm{~kg} / \mathrm{hr}$., the productivity increased with all treatments in average of $132.66 \mathrm{~kg}$, then it decreased slightly in average of $28.4 \mathrm{~kg}$ at feed rate of $400 \mathrm{~kg} / \mathrm{hr}$. This increase could be due to increasing the drag force for the movement of ration inside the screw cylinder, on the other hand, the increase of the ration quantities which passed through the extrusion unit and outputted from the die holes at the same time unit, this may lead to higher productivity. The decreasing productivity in high feed could be due to the high amount of ration which transfer from the screw feeding zone to the die zone quickly through constant output area that tend to block extruder cylinder.

It is also observed that, increasing the holes diameter from 8 to $14 \mathrm{~mm}$ at feeding rate of 300 $\mathrm{kg} / \mathrm{hr}$., increased the productivity from 135.34 to 241.68, 119.11 to 212.71 and 106.26 to189.76 $\mathrm{kg} / \mathrm{hr}$., for the control ration, $12.5 \%$ rice straw replacement and 25\% rice straw replacement, respectively. This increase may be attributed to the number of holes in the surface of the die, and this leads to reduce the internal friction between the ration and the internal die surface, so the pressure will increase and then give more production.

The obtained data showed that, increasing the distance between the screw and die from 1 to $2 \mathrm{~cm}$ lead to reduce the productivity from 119.11 to $94.57 \mathrm{~kg} / \mathrm{hr}$., at feeding rate of 300 $\mathrm{kg} / \mathrm{hr}$., die of $8 \mathrm{~mm}$ and $12.5 \%$ of rice straw replacement. This decrease could be due to the ration take more time to cross the distance between the screw and the die and this mean more lost time and less productivity.

It was noticed that, increasing in rice straw percentage in the standard ration from 12.5 to $25 \%$ reduced the production rate from 119.11 to $106.26 \mathrm{~kg} / \mathrm{hr}$., at feeding rate of $300 \mathrm{~kg} / \mathrm{hr}$., die of $8 \mathrm{~mm}$, screw-die distance of $1 \mathrm{~cm}$. This could be explained as the rice straw is fibrous material so more power consumed to press the rice straw and this means more time lost and less productivity.

The highest value of productivity which was achieved at the highest values of pelleting efficiency, pellet bulk density and durability was $92.34 \mathrm{~kg} / \mathrm{hr}$., whereas, the lowest productivity of $15.41 \mathrm{~kg} / \mathrm{hr}$., was recorded at feeding rate of 100 $\mathrm{kg} / \mathrm{hr}$., die of $8 \mathrm{~mm}$, screw-die distance of $2 \mathrm{~cm}$ and $25 \%$ rice straw replacement.

\section{Effect of Some Operating Parameters on Pellets Bulk Density}

Bulk density is one of the most critical and important quality indicators. Fig. 5 show that, 
Die- screw distance ,cm
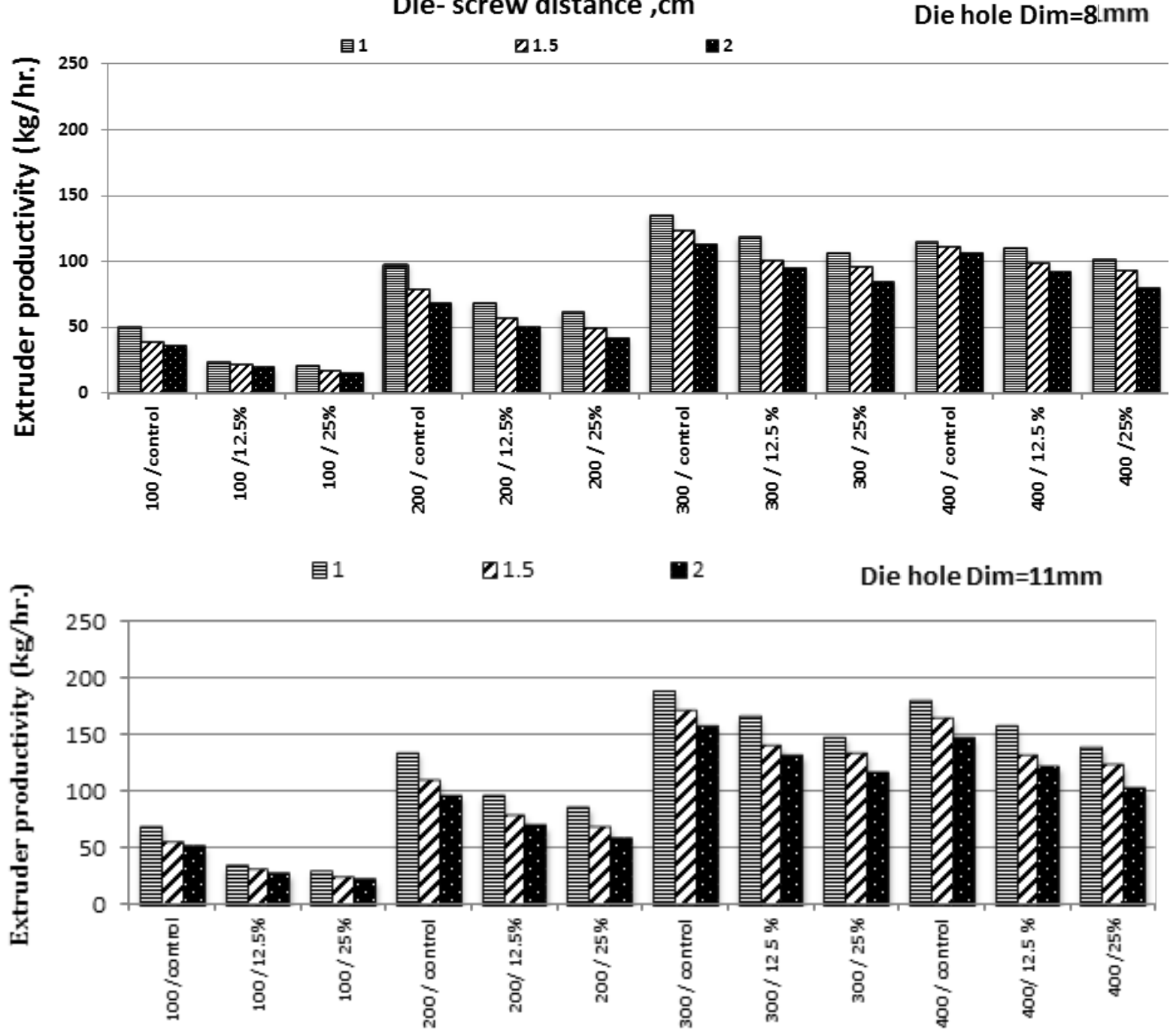

目1

Z1.5

- 2

Die hole Dim=14mm

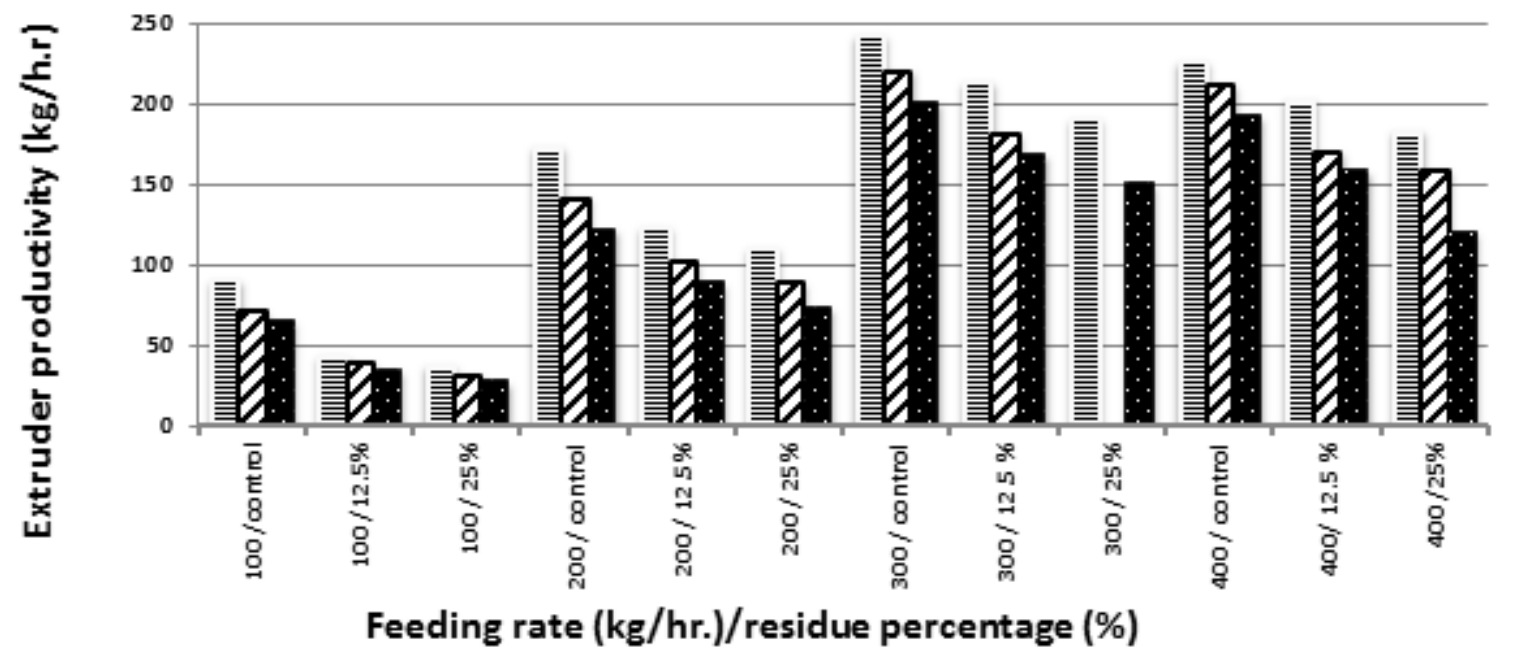

Fig. 4. Effect of some operating parameters on extruder productivity 
Die- screw distance ,cm
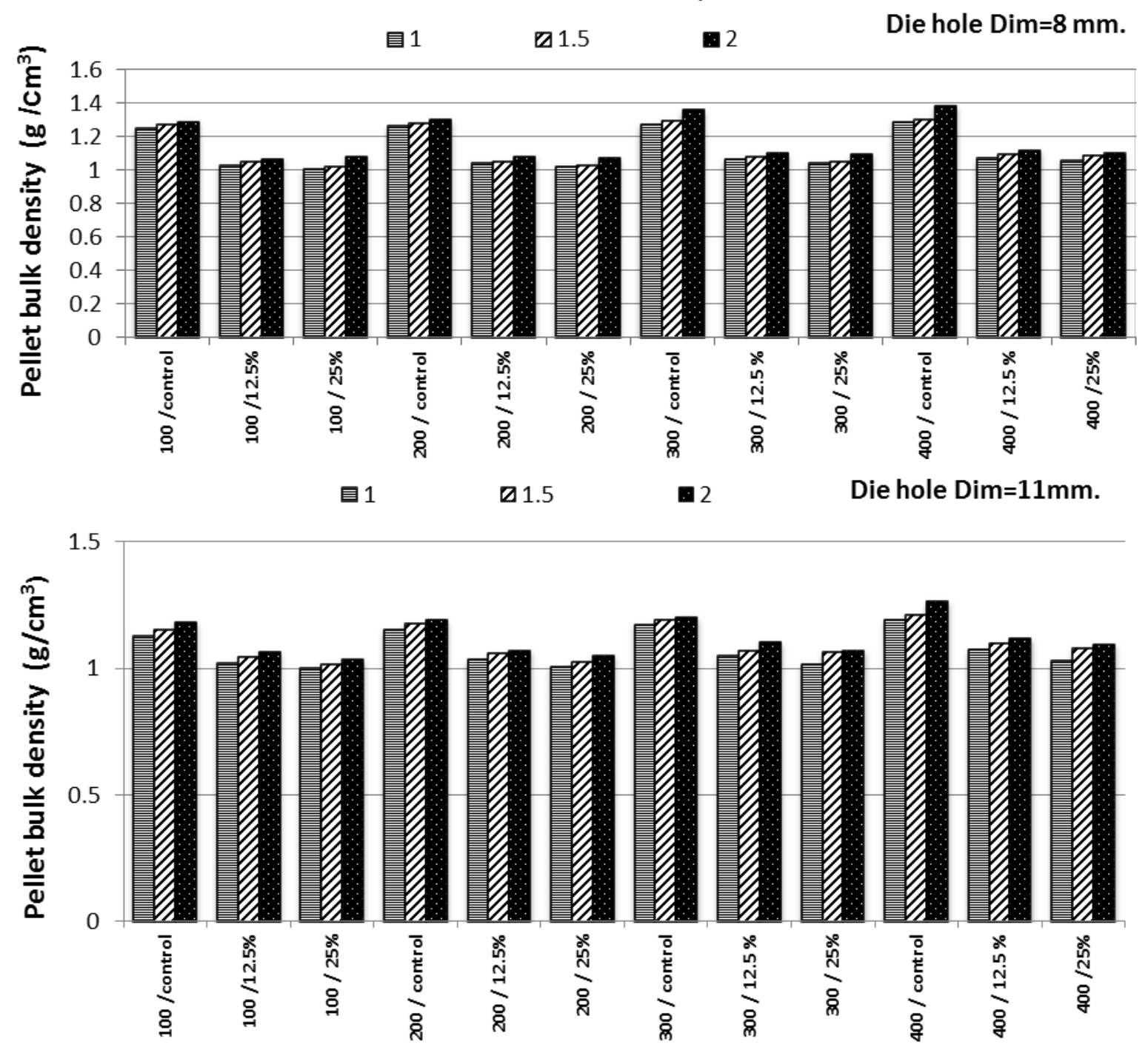

目1

②.5

a 2

Die hole Dim=14mm.

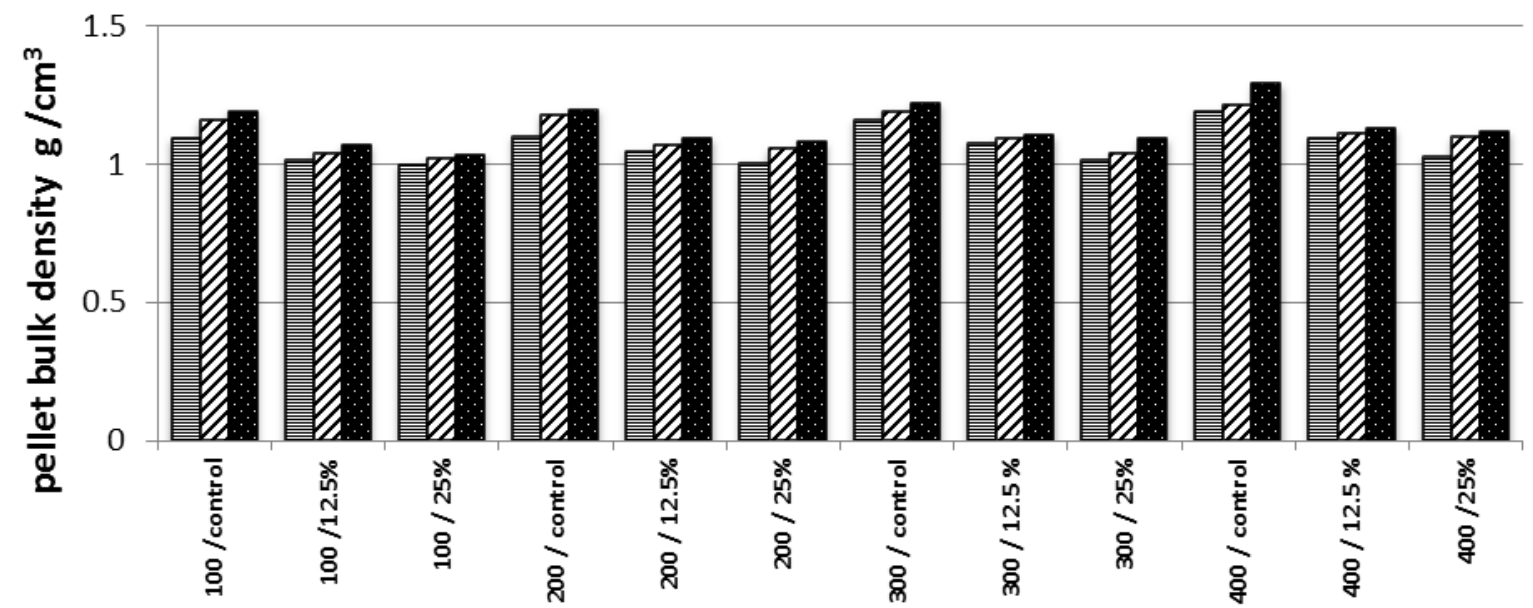

Feeding rate $(\mathrm{kg} / \mathrm{hr}$.)/residue percentage (\%)

Fig. 5. Effect of some operating parameters on pellet bulk density 
increasing feed rate from 100 to $400 \mathrm{~kg} / \mathrm{hr}$., increased the bulk density with all treatments. It was increased from 1.034 to $1.073 \mathrm{~g} / \mathrm{cm}^{3}$ at die 8 $\mathrm{mm}$, screw-die distance of $1 \mathrm{~cm}$ and $12.5 \%$ rice straw replacement. This could be due to increasing in homogenizing of ration granules caused more compaction of the raw materials in the die zone that means increasing in granules mass in the same volume of die holes for the obtained pellets.

It is also observed that, increasing hole diameter from 8 to $14 \mathrm{~mm}$ decreased the pellets bulk density with all treatments. It was decreased from 1.067 to $1.030 \mathrm{~g} / \mathrm{cm}^{3}$ at feeding rate of $300 \mathrm{~kg} / \mathrm{hr}$., screw-die distance of $1 \mathrm{~cm}$ and $12.5 \%$ rice straw replacement. This could be explained as the number of holes in the surface of the die, as all dies have the same open area $\left(153.86 \mathrm{~mm}^{2}\right)$, the die $14 \mathrm{~mm}$ has 8 holes, the die $11 \mathrm{~mm}$ dim has 13 holes and die $8 \mathrm{~mm}$ dim has 25 holes and this may lead to reduce the resistance force in high diameter and this mean less compression, so the mass unit will decrease, then the bulk density will decrease.

The obtained data showed that, increasing the distance between the screw and die leads to increase the pellets bulk density. It was increased from 1.067 to $1.101 \mathrm{~g} / \mathrm{cm}^{3}$ at feeding rate of $300 \mathrm{~kg} / \mathrm{hr}$., die of $8 \mathrm{~mm}$ and $12.5 \%$ rice straw replacement. This could be due to the ration take more time to cross the distance between the screw and the die and this means more retention time and more pressure leading to more cohesion among the granules, the pellets mass unit will increase leads to more bulk density.

It was noticed that, increasing in rice straw percent in the standard ration from 12.5 to $25 \%$ leads to reduce the pellets bulk density. It was decreased from 1.067 to $1.046 \mathrm{~g} / \mathrm{cm}^{3}$ at feeding rate of $300 \mathrm{~kg}$, die of $8 \mathrm{~mm}$ and screw -die distance of $1 \mathrm{~cm}$. This could be due to that rice straw is a fibrous material which has a little weight and big volume and this means less bulk density.

The results stated that, the optimum value of bulk density of $1.121 \mathrm{~g} / \mathrm{cm}^{3}$ was achieved at $12.5 \%$ rice straw replacement with die $8 \mathrm{~mm}$, screw-die distance of $2 \mathrm{~cm}$ and feed rate of 400 $\mathrm{kg} / \mathrm{hr}$., whereas, the lowest bulk density was recorded at $25 \%$ rice straw replacement with die $14 \mathrm{~mm}$, screw-die distance of $1 \mathrm{~cm}$ and feed rate of $100 \mathrm{~kg} / \mathrm{hr}$.

\section{Effect of Some Operating Parameters on Pellets Durability}

In the feed industry, high durability means high quality and good pellets. Fig. 6 display that, increasing feed rate from 100 to $400 \mathrm{~kg} / \mathrm{hr}$., increased the pellets durability with all treatments. It was increased from 77.63 to $85.48 \%$ at die of $8 \mathrm{~mm}$; screw-die distance of 1 $\mathrm{cm}$ and $12.5 \%$ rice straw percentage. This could be due to increasing in the raw material pressure inside die holes and that leads to increase pellets piece density so not easy to broken under durability treatment.

It is also observed that, increasing in holes diameter from 8 to $14 \mathrm{~mm}$ decreased the pellets durability with all treatments. It was decreased from 83.42 to $77.42 \%$ at feeding rate of 300 $\mathrm{kg} / \mathrm{hr}$., screw-die distance of $1 \mathrm{~cm}$ and $12.5 \%$ rice straw percentage. Despite, all forming dies have the same opening area the increase of the hole diameter would lead to reduce the resistance force in high diameter and this mean less compression and more broken pellets.

The obtained data showed that, increasing the distance between the screw and die leads to increasing the pellets durability because the ration take more time to cross the distance between the screw and the die and this mean more retention time and more pressure leading to more cohesion between the granules. It was increased from 83.42 to $89.13 \%$ at feeding rate of $300 \mathrm{~kg} / \mathrm{hr}$., die of $8 \mathrm{~mm}$ and $12.5 \%$ rice straw percentage.

It was noticed that, increasing the rice straw replacement percentage in the standard ration would reduce the pellets durability with all treatments. It was decreased from 83.42 to $77.64 \%$ at feeding rate of $300 \mathrm{~kg}$, die of $8 \mathrm{~mm}$ and screw-die distance of $1 \mathrm{~cm}$. This decrease may attributed to the rice straw is a fibrous material which penetrate the bonds among the ration granules and reduce the cohesion of pellet component leading to less pellet durability and more broken pellets.

The highest value of pellet durability of $90.70 \%$ was achieved at feed rate of $400 \mathrm{~kg} / \mathrm{hr}$., with die $8 \mathrm{~mm}$, screw- die distance of $2 \mathrm{~cm}$ and $12.5 \%$ rice straw replacement whereas, the lowest value of pellet durability was recorded at feed rate of $100 \mathrm{~kg} / \mathrm{hr}$., with die $14 \mathrm{~mm}$, screwdie distance of $1 \mathrm{~cm}$ and $25 \%$ rice straw replacement. 
Die -screw distance, $\mathrm{cm}$
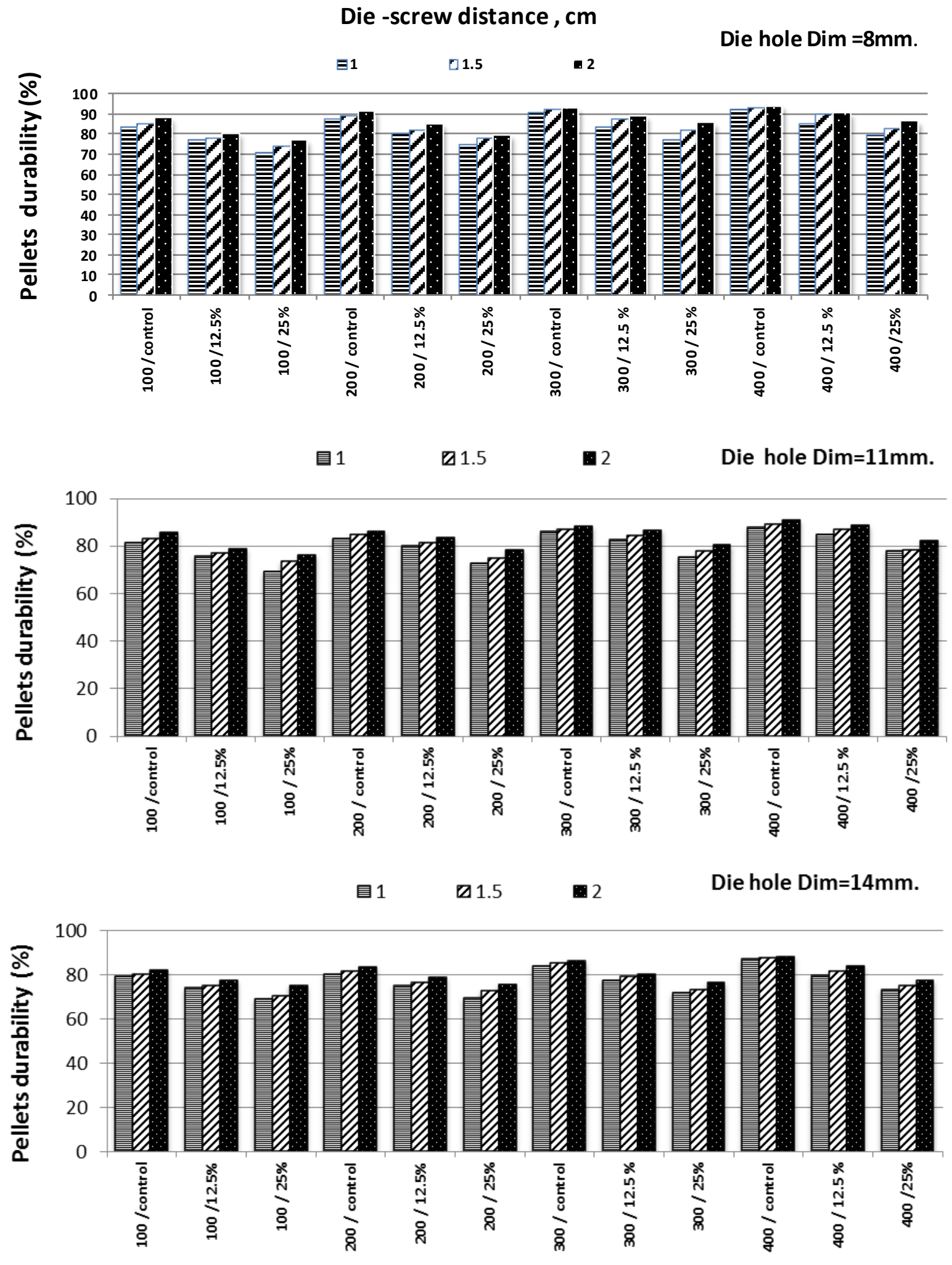

Feeding rate $(\mathrm{kg} / \mathrm{hr}$.$) / residue percentage (\%)$

Fig. 6. Effect of some operating parameters on pellets durability 


\section{Effect of Some Operating Parameters on Pelleting Efficiency}

Pelleting efficiency is an important indicator for pelleting quality. Fig. 7 illustrate that, increasing feed rate from 100 to $400 \mathrm{~kg} / \mathrm{hr}$., leads to increase pellets efficiency with all treatments. It was increased from 74.11 to $79.14 \%$ at die $8 \mathrm{~mm}$, screw-die distance of $1 \mathrm{~cm}$ and $12.5 \%$ rice straw percentage. This increase could be due to increasing the amount of pellets causing high pressure, make more bonds and natural lubricants between the granules and then leads to more efficiency.

It is also observed that, increasing the hole diameter from 8 to $14 \mathrm{~mm}$ decreased the pellets efficiency with all treatments. It was decreased from 77.53 to $74.14 \%$ at die of $8 \mathrm{~mm}$, screw-die distance of $1 \mathrm{~cm}$ and $12.5 \%$ rice straw percentage. This decrease could be attributed to the reduce of the resistance force in high diameter and this mean less compression and more broken pellets.

The obtained data showed that, increasing the distance between the screw and die followed by increasing in pellets efficiency. It was increased from 77.53 to $81.03 \%$ at feeding rate of $300 \mathrm{~kg} / \mathrm{hr}$., die of $8 \mathrm{~mm}$ and $12.5 \%$ rice straw percentage. This increase because the ration take more time to cross the distance between the screw and the die and this mean more retention time and more pressure leading to more cohesion between the granules.

It was noticed that, increasing in rice straw replacement percentage from 12.5 to $25 \%$ in the standard ration reduced the pellets efficiency. It was decreased from 77.53 to $66.02 \%$ at feeding rate of $300 \mathrm{~kg} / \mathrm{hr}$., die of $8 \mathrm{~mm}$ and screw-die distance of $1 \mathrm{~cm}$. This could be due to the rice straw is a fibrous material which reduces the cohesion force among the pellet granules and lead to more deformation and broken pellets.

The highest value of pellets efficiency of $82.52 \%$ was achieved at feed rate of $400 \mathrm{~kg} / \mathrm{hr}$., with die $8 \mathrm{~mm}$, screw-die distance of $2 \mathrm{~cm}$ and $12.5 \%$ rice straw replacement whereas, the lowest value of pellets efficiency of $60.62 \%$ was recorded at feed rate of $100 \mathrm{~kg} / \mathrm{hr}$., with die 14 $\mathrm{mm}$, screw-die distance of $1 \mathrm{~cm}$ and $25 \%$ rice straw replacement.

\section{Effect of Some Operating Parameters on Specific Energy Requirement}

The cattle feed pellets energy requirement depends theoretically on consumed power and machine productivity. Fig. 8 show that, increasing feed rate from 100 to $300 \mathrm{~kg} / \mathrm{hr}$., decreasing the energy requirement from 832.10 to $183.58 \mathrm{~kW} . \mathrm{hr} . / \mathrm{Mg}$ at die of $8 \mathrm{~mm}$, screw-die distance of $1 \mathrm{~cm}$ and $12.5 \%$ rice straw percentage and slightly increased from 183.58 to $208.04 \mathrm{~kW} . \mathrm{hr} . / \mathrm{Mg}$ at feeding rate of $400 \mathrm{~kg} / \mathrm{hr}$. The decreasing in energy requirement by increasing feed rate up to $300 \mathrm{~kg} / \mathrm{hr}$., could be due to the increase of the extruder productivity in the same time unit more than the increase of the required power. The increasing in energy requirement in high feed rate could be due to the high amount of ration which transfer from the screws feeding zone to the die zone quickly through constant output area which tend to accumulate and block the extruder cylinder, resulting in over load in the extruder main motor and reduction in screw speed so long time is required to remove the blocked ration and consequently more power will be lost and more energy required.

It is also observed that, increasing hole diameter from 8 to $14 \mathrm{~mm}$ decreased the energy requirement with all treatments. It was decreased from 183.58 to $65.41 \mathrm{kw} . \mathrm{hr} . / \mathrm{Mg}$ at feeding rate of $300 \mathrm{~kg} / \mathrm{hr}$., screw-die distance of $1 \mathrm{~cm}$ and $12.5 \%$ rice straw percentage. This decrease could be due to the reduce the internal friction between the ration and the internal die surface so the pressure will increase and this leads to more production and the power will reduce as the friction force will decrease in high diameter hole.

The obtained data showed that, increasing the distance between the screw and die leads to increasing the energy requirement with all treatments. It was increased from 183.58 to $252.24 \mathrm{~kW} . \mathrm{hr} . / \mathrm{Mg}$ at feeding rate of $300 \mathrm{~kg} / \mathrm{hr}$., die of $8 \mathrm{~mm}$ and $12.5 \%$ rice straw percentage. This increase could be due to the ration take more time to cross the distance between the screw and the die and this mean more lost time, less productivity and more power resulting more energy requirement. 

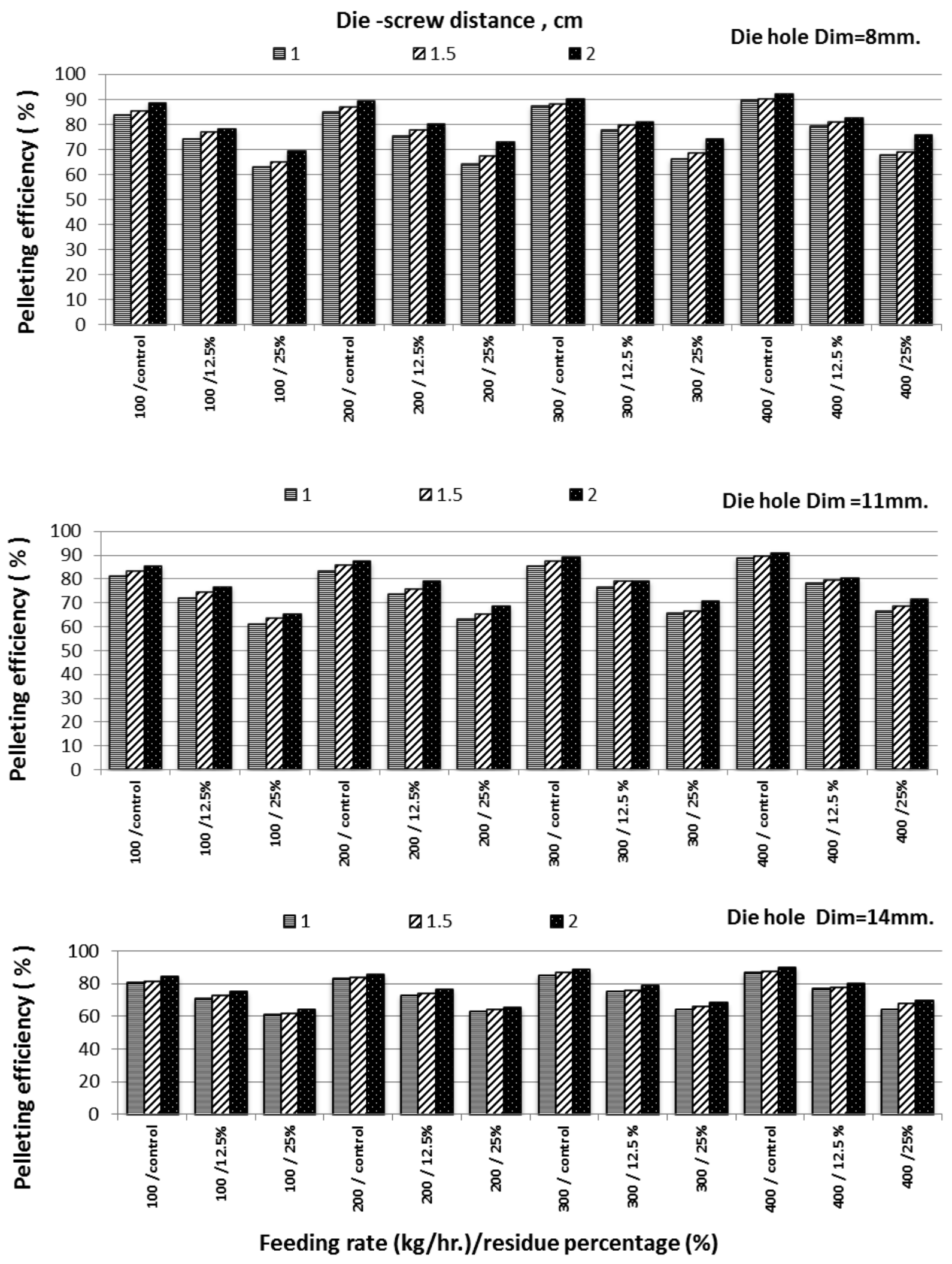

Fig. 7. Effect of some operating parameters on pelleting efficiency 
Die -screw distance,cm
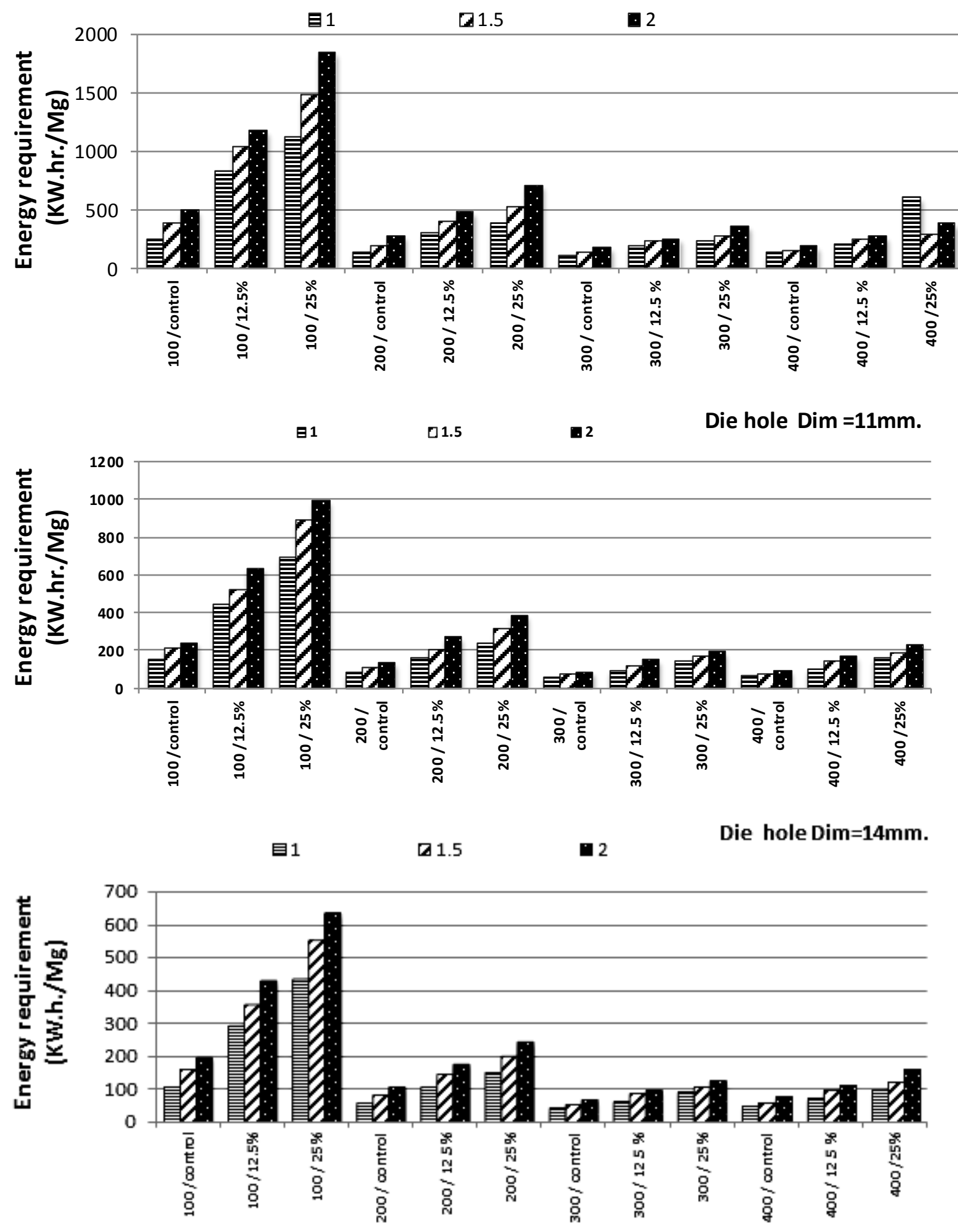

Feeding rate (kg/hr.)/residue percentage (\%)

Fig. 8. Effect of some operating parameters on energy requirement 
It was noticed that, increasing the rice straw percentage in the standard ration from 12.5 to $25 \%$ increased the energy requirement. It was decreased from 183.58 to 229.17 kW.hr./Mg at feeding rate of $300 \mathrm{~kg} / \mathrm{hr}$., screw- die distance of $1 \mathrm{~cm}$ and die of $8 \mathrm{~mm}$. This increase could be due to the rice straw is fibrous material so more power will be lose in compression and productivity will reduce leading to more energy requirement.

The lowest value of energy requirement of $65.41 \mathrm{~kW} . \mathrm{hr} . \mathrm{Mg}$ was achieved at feed rate of $300 \mathrm{~kg} / \mathrm{hr}$., with die $14 \mathrm{~mm}$, screw-die distance of $1 \mathrm{~cm}$ and $12.5 \%$ rice straw replacement whereas, the highest value of $1838.28 \mathrm{~kW} . \mathrm{hr} . /$ $\mathrm{Mg}$ was recorded at feed rate of $100 \mathrm{~kg} / \mathrm{hr}$., with die $8 \mathrm{~mm}$, screw-die distance of $2 \mathrm{~cm}$ and $25 \%$ rice straw replacement.

\section{Effect of some operating parameters on total cost}

Reducing the product cost the aim of any industry. Fig. 9 illustrate that, increasing feed rate from 100 to $300 \mathrm{~kg} / \mathrm{hr}$., leads to decrease total cost from 2806.13 to $2327.85 \mathrm{LE} / \mathrm{Mg}$ at die of $8 \mathrm{~mm}$, screw-die distance of $1 \mathrm{~cm}$ and 12.5\% rice straw percentage and slightly increase from 2327.85 to $2358.94 \mathrm{LE} / \mathrm{Mg}$ in feed rate of $400 \mathrm{~kg} / \mathrm{hr}$. This could be due to increasing the extruder productivity in the same time unit more than the increase of the required power, but any further increase in feed rate leads to increase pelleting cost at the higher feed rate and this could be due to the high amount of ration which transfer from the screw feeding zone to the die zone quickly through constant output area that tend to block extruder cylinder, resulting in over load in the extruder main motor and reduction in screw speed so long time is required to remove the blocked ration and then more power will be lost and more energy requirement leading to more cost.

It is also observed that, increasing the hole diameter from 8 to $14 \mathrm{~mm}$ decreased the total cost. It was decreased from 2327.85 to 2272.94 $\mathrm{LE} / \mathrm{Mg}$ at feeding rate of $300 \mathrm{~kg} / \mathrm{hr}$., screw-die distance of $1 \mathrm{~cm}$ and $12.5 \%$ rice straw percentage. This could be due to the increasing of the machine productivity that occurred will be higher than the occurred with power.
The obtained data showed that, increasing the distance between the screw and die leads to increasing the total cost with all treatments. It was increased from 2327.85 to $2386.15 \mathrm{LE} / \mathrm{Mg}$ at feeding rate of $300 \mathrm{~kg} / \mathrm{hr}$., die of $8 \mathrm{~mm}$ and $12.5 \%$ rice straw percentage. This could be due to the ration takes more time to cross the distance between the screw and the die and this mean more lost time, less productivity and more power leading to more energy requirement, increasing in the power and energy requirement will increase the total cost.

It is noticed that, increasing in rice straw percent in the standard ration from 12.5 to $25 \%$ decreased the pelleting cost. It was decreased from 2327.85 to $2084.14 \mathrm{LE} / \mathrm{Mg}$ at feeding rate of $300 \mathrm{~kg} / \mathrm{hr}$., die of $8 \mathrm{~mm}$ and screw-die distance of $1 \mathrm{~cm}$.

This could due to the rice straw is priceless material so the total cost of ration components will reduce by replacement.

Despite, the 25\% rice straw replacement was achieved the lowest cost of $2002.90 \mathrm{LE} / \mathrm{Mg}$ at feed rate of $300 \mathrm{~kg} / \mathrm{hr}$., with die $14 \mathrm{~mm}$ and screw- die distance of $1 \mathrm{~cm}$. It is recommended to take the $12.5 \%$ rice straw replacement which recorded $2394.90 \mathrm{LE} / \mathrm{Mg}$ at the highest values of bulk density, pellet durability and pelleting efficiency using feed rate of $400 \mathrm{~kg} / \mathrm{hr}$., with die $14 \mathrm{~mm}$, screw die distance of $2 \mathrm{~cm}$ and $12.5 \%$ rice straw percent. The obtained data showed that, using rice straw with $12.5 \%$ in the standard ration saved about $236.91 \mathrm{LE} / \mathrm{Mg}$ from total cost.

\section{Conclusion}

According to the obtained results, It is recommended to operate the extrusion machine using feed rate of $400 \mathrm{~kg} / \mathrm{hr}$., die hole diameter of $8 \mathrm{~mm}$, screw-die distance of $2 \mathrm{~cm}$ and rice straw replacement of $12.5 \%$ to achieve the highest values of bulk density of $1.121 \mathrm{~g} / \mathrm{cm}^{3}$, pellet durability of $90.70 \%$ and pelleting efficiency of $82.52 \%$ with machine productivity of $92.34 \mathrm{~kg} / \mathrm{hr}$., energy requirement of 269 kW.hr./Mg and total cost of $2394.90 \mathrm{LE} / \mathrm{Mg}$. The obtained data recommended to use rice straw with $12.5 \%$ in the standard cattle ration to save about 236.91 LE/Mg from total cost. 
Die -screw distance, $\mathrm{cm}$

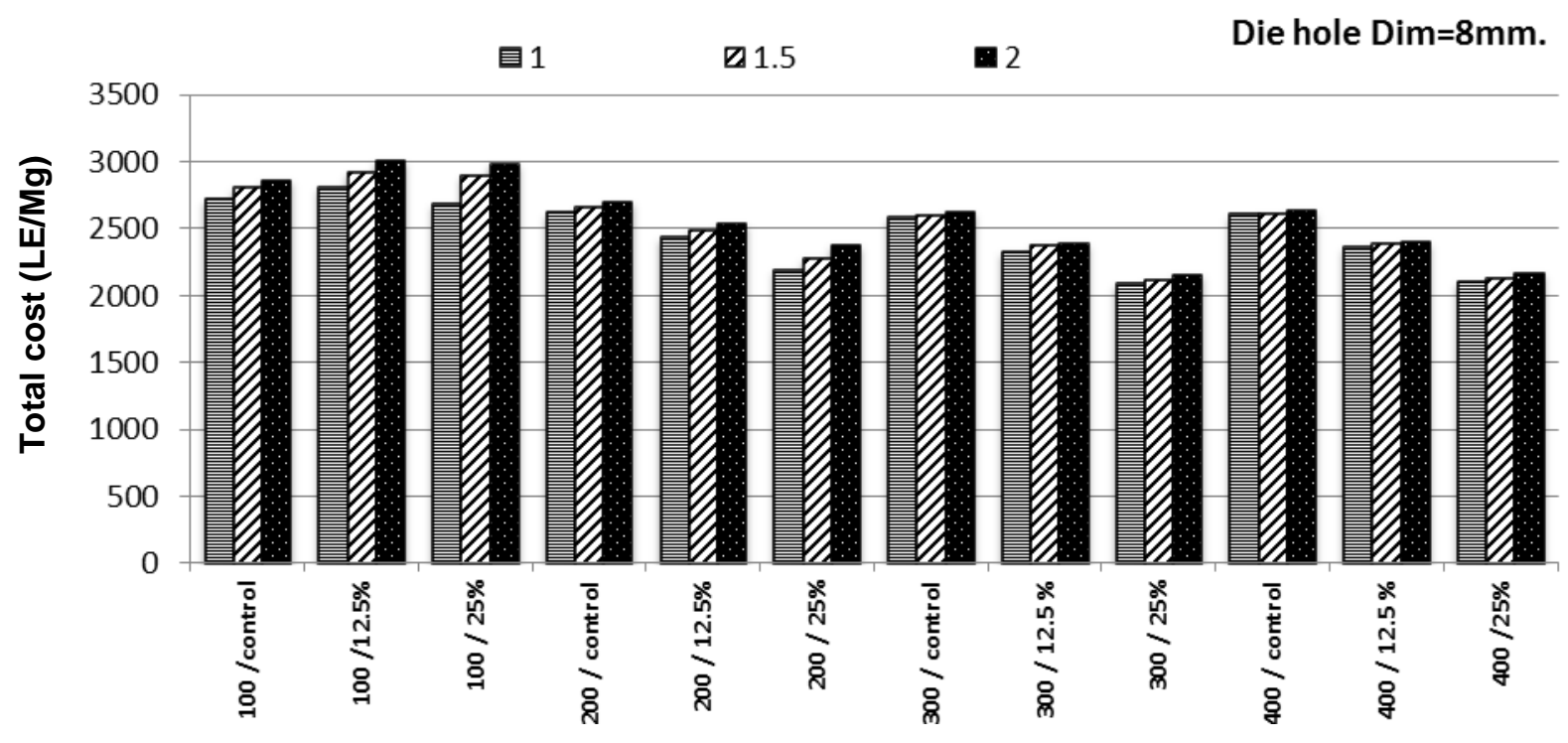

目 1

$\square 1.5$

. 2

Die hole Dim =11mm.
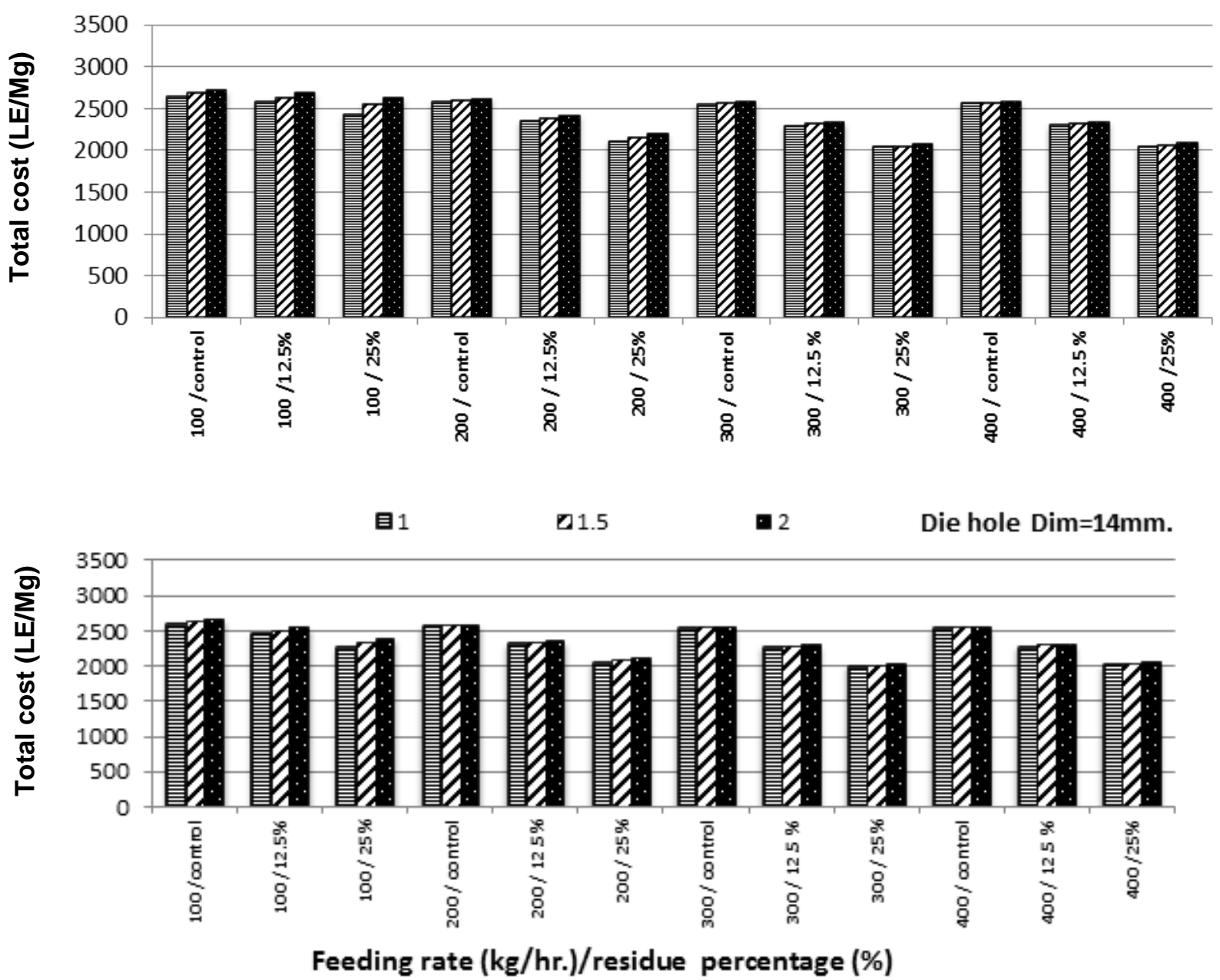

Fig. 9. Effect of some operating parameters on total cost 


\section{REFERENCES}

Abdel-Motteleb, A.F. (1993). A study of crushing machines for the agricultural field raw material for industrialization and factors affecting the softness degree and pink boll worms control. M. Sc. Fac. Agric. Agric. Eng. Dept. Zagazig Univ.

ASAE (1996). American Society of Agricultural Engineers Standers-Engineering Practices, and Data, ASAE standard book.

Behnke, K.C. (1994). Factors affecting pellet quality. Proc. Maryland Nut. Conf., Poult. Anim. Dept., Coll. Agri., Maryland Univ., 20-25.

Blass, C.D. and J. Wiseman (1998). The nutrition of the rabbit CAPT publishing, C A B International, Ch., 12, 14: 215-239, 255-271.

Devendra, C. and C.C. Sevilla (2002). Availability and use of feed resources in crop animal systems in Asia. Agric. Syst., 1: 59-74.

Dobermann, A. and T. Fairhurst (2000). Rice Nutrient disorders and nutrient management Book. Potash and Phosphate Inst. (Singapore) and Int. Rice Res. Inst., 191.

El-Zahaby, A.M. (1996): Techno- economic study on utilization of some field crop residues, Ph.D. Thesis (Ag. Eng.), Fac. Agric., Cairo Univ.

Environmental Statistics (2014). Economic Affairs Sector, environmental ministry, Cairo, Egypt.

Gaur, A.C. and K.V. Sadasivam (1993). Theory and practical considerations of composting organic wastes. pp: 1-22 In: HSL. Tandon (ed.) Organics in Soil Health and Crop Production. Peaky Tree Crops Develop. Foundation, Cochin.

Gupta, P.D. and R.K. Goyal (1999). Pelletization of different animal feeds using IGFRI pelleting machine-an analysis of feeding trial processing Equip. and Technol., 20 (1): 70-77.

Harper, J.M. and G.R. Jansen (1981). Nutritious foods produced by low-cost technology. LEC Report, 10.

Hauck, B. W. (1993). Choosing an extruder. In: A. Turner (ed.) Food Technol. Int. Europe. Sterling Publications Int., London, 81-82.
Kaddour, U.A.K. (1999). Development of a simple crushing and milling machine for field residues suits the 5 mall farms. Ph.D. Thesis. Fac. Agric. Eng. Dept. Zagazig Univ. Egypt.

Kaddour, U.A.K. (2003). Development of a local pelleting machine to produce fish feed meal cook pellets. The $11^{\text {th }}$ Annual Conf. of Misr Soc. Agric. Eng. Meet El-Deeba, Kafr El- Sheihk, 15-16 October : 538-556.

Kaddour, U.A.K., T.R. Awes and M.K Afify (2006). Influencing of geometric dimension of extrusion die holes on machine efficiency and pellets quality. Conf. Mansoura Univ., J. Agric. Sci., 31 (7) : 337-359.

Kurt, G. (1979). Engineering Formulas. $3^{\text {rd }}$ Ed. Mc Graw- Hill book Co.

NRC (2001). National Research Council. Nutrient requirements of dairy cattle, seventh rev. ed. Natl. Acad. Sci., Washington, DC, USA. Poore, M.H., Moore, J.A., Swingle, R.S., Eck, T.P., Brown, W.H., 1991. Wheat straw or alfalfa hay in diets with $30 \%$ neutral detergent fiber for lactating Holstein cows. J. Dairy Sci., 74: 3152-3159.

Nehru, C., A.R. Kurt and K. Muthukmarappan (2005). Utilization of distillers dried grains for fish feed by extrusion technology A Review. 2.5 ASAE Annual International Meeting Spocnsored by ASAE., Tampa Convention Center, Tampa, Florida, 17-20.

Turner, R. (1995). Bottomline in feed processing: achieving optimum pellet quality. Feed Manag, 46: 30-33.

Wanapat, M., N.T. Huyen and C. Navanukrawo (2012). Effect of mulberry leaf pellet (Mup) supplementation on rumen fermentation and nutrient digestibility in beef fed on rice straw - based diets. Anim. Feed Sci. and Technol., 175:8-15.

Watfa, Y .A. (1999). A study on machinery used in forming of grain chaff by pressing and bonding. M.Sc. Thesis. Agric. Eng. Fac. Agric Ain Shams Univ.

Zaki, R.I., M.S. El-Shal and M.E.I Radwan (2014). Effect of preconditioner operating parameters on the physical and chemical quality of extruded fish pellets. Zagazig J. Agric. Res., 41 (4): 877-886. 


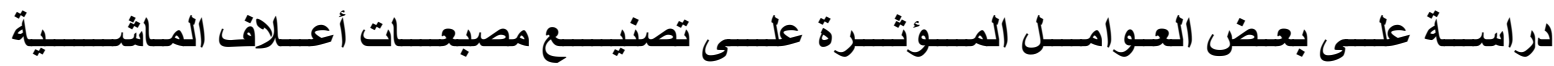

محمود محمد أحمد بكر' - محمود عبدالرحمن الشاذلى' - محمد على توفيق ‘ - ياسر صبح عبدالله ‘

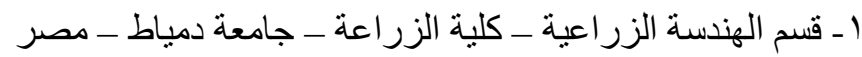

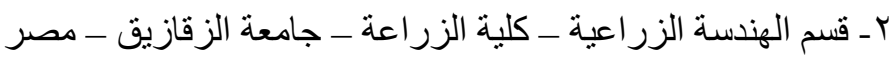

تهدف هذه الدراسة إلى تقييم أداء آلة البثق لإنتاج مصبعات أعلاف مانشية على درجة عالية من القوة و المتانة بأقل

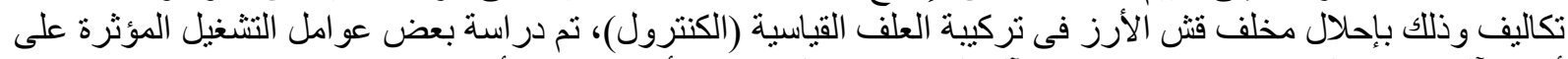

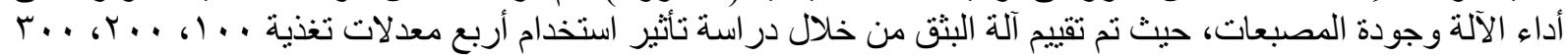

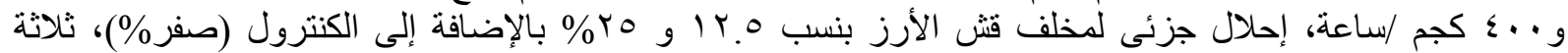

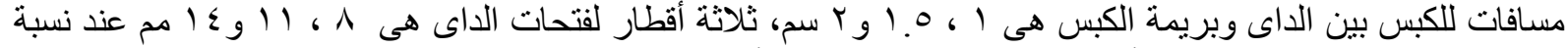

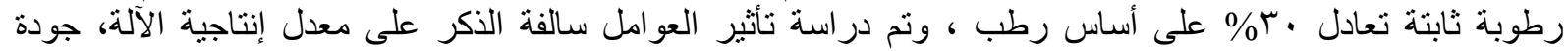

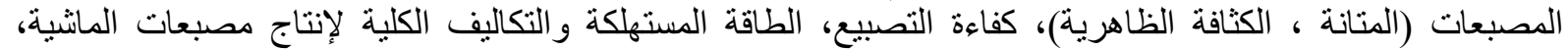

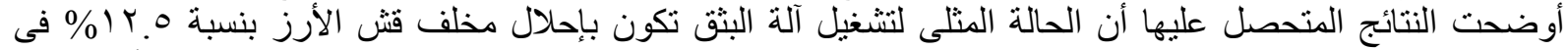

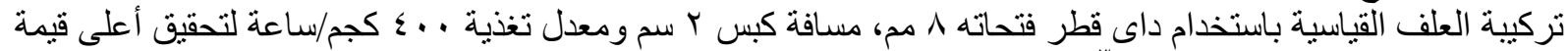

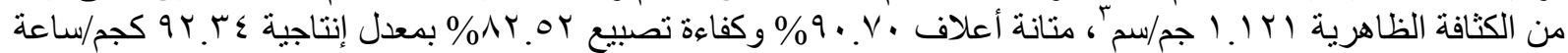

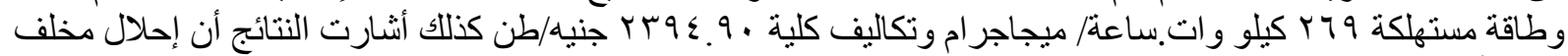

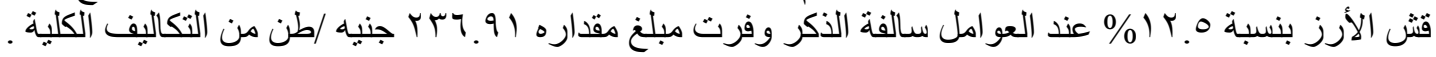

